\title{
CSSR2019
}

6th International Conference on Science \& Social Research 2019

https://cssr.uitm.edu.my/2019/

Parkroyal Penang Resort, Batu Ferringhi, Pulau Pinang, Malaysia, 04-05 Dec 2019

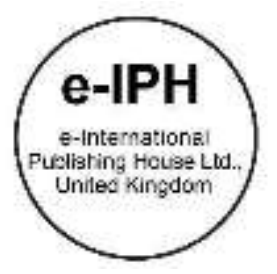

\section{Determination of Zone-based Solah Times: A Practice in Malaysia}

\author{
Mohd Paidi Norman, Mohd Zaid Daud, \\ Mohd Solahuddin Shahruddin, Sharifah Fadylawaty Syed Abdullah
}

\author{
Akademi Pengajian Islam Kontemporari, Universiti Teknologi MARA, 40450 Shah Alam, Selangor, Malaysia \\ apai_norman@salam.uitm.edu.my, mohdzaid@uitm.edu.my, msolahuddin@uitm.edu.my, fadylawaty4935@uitm.edu.my \\ Tel of 1 st Author: +60133269734
}

\begin{abstract}
Zone-based solah times depend on the Earth's orbital movement around the sun. JAKIM has introduced zone-based solah times prescribes the times for the zones or areas. Nevertheless, the on-site calculation of zonal solah times is often informed by geographical and state Islamic affairs administrations. This study aims to survey the practices and methods employed to determine the Malaysian states' zonal solah times, using library research and interview approaches. The findings indicated that two typical methods used are the Westernmost Point and Multipoint Reference. Another alternative method provided by Falak experts is Isotime.
\end{abstract}

Keywords: Zones Solah Times, Multi-Point Reference, West-most Point

eISSN: 2398-4287@ 2021. The Authors. Published for AMER ABRA cE-Bs by e-International Publishing House, Ltd., UK. This is an open access article under the CC BYNC-ND license (http://creativecommons. org/licenses/by-nc-nd/4.0/). Peer-review under responsibility of AMER (Association of Malaysian Environment-Behaviour Researchers), ABRA (Association of Behavioural Researchers on Asians/Africans/Arabians) and cE-Bs (Centre for Environment-Behaviour Studies), Faculty of Architecture, Planning \& Surveying, Universiti Teknologi MARA, Malaysia.

DOI: https://doi.org/10.21834/ebpj.v6iSI4.2918

\subsection{Introduction}

Solah is a badaniah or physical worship (Mustofa, 2003), referring to worship's physical movements. Solah is the pillar of Islam, and Allah SWT commands the Muslims to perform solah wherever they may be within the time specified. Nowadays, the determination of solah times is based not only on the al Qu'ran and al Hadiths perspective but also involved Falak and astronomy calculating techniques, which help the practicality of praying times in daily performance. Besides, modern technological aids make the computation of zonal solah times even more accurate and meet the shariah requirement that solah is performed as soon as possible (Saupi, 1994). This study aims to survey the practices and methods employed to determine the zonal solah times in the Malaysian states.

\subsection{Literature Review}

Zone refers to the surface area of the Earth that is located at points of longitude and latitude. Time zones are defined as an area in the world with similar time zones or local times. The determination and specification of the solar times are based on the movement and position of the sun. For example, in a particular area, Zuhr begins when the sun is on the local meridian of the place at noon, according to the sun, not according to the time zone. Although the time zone refers to solar time, i.e., the sun's motion, it is not the sun's actual movement. The time zone system is calculated and specified based on longitude (R.B. Bunnet, 1970) and some boundary, facilitating a particular zone's daily life and between zones with another zone.

World time zones shall be determined by a longitudinal range of $15^{\circ}$ each, equivalent to 1 hour or $7.5^{\circ}$ equivalent to 30 minutes. Malaysia uses only one reference line at $120^{\circ}$ east longitude. For example, in normal circumstances, the time of Zuhr in Sabah and Terengganu is different, with the time of Zuhr in Sabah 1 hour before Zuhr in Terengganu, although the time of the clock in both states

eISSN: 2398-4287@ 2021. The Authors. Published for AMER ABRA cE-Bs by e-International Publishing House, Ltd., UK. This is an open access article under the CC BYNC-ND license (http://creativecommons.org/licenses/by-nc-nd/4.0/). Peer-review under responsibility of AMER (Association of Malaysian Environment-Behaviour Researchers), ABRA (Association of Behavioural Researchers on Asians/Africans/Arabians) and cE-Bs (Centre for Environment-Behaviour Studies), Faculty of Architecture, Planning \& Surveying, Universiti Teknologi MARA, Malaysia.

DOI: https://doi.org/10.21834/ebpj.v6iSI4.2918 
is the same. That being the case, the actual solar motion and position are referred to the solar time. This situation indirectly causes variation in the solar time between states, districts, and even villages, due to differences in the preferred stations' coordinates.

As a result of these issues, solar zoning times are introduced to coordinate the computation of solah times for the whole state zone based on the specific reference points (5-007) applicable to the populated zone. This point means that the determination of solah times is carried out in zones according to their divisions, such as district and sub-district, due to differences in latitude and longitude points. This situation enables the systematic identification of each specific solar time for an area, thus complying with the shariah requirements.

Nevertheless, there is still a lack of a uniform policy for determining solar time zones in Malaysia, resulting in too many solah zones, up to 168 in number (Utusan Melayu, February 6 1995). The number of zones was reduced to 66 (Berita Harian, January 25, 1996) and finally to 42 zones (Berita Harian, December 30 1998). However, the zones have since been increased to 49 nationally (Berita Harian, October 13, 2006), that currently, the total number of zones in Malaysia is 56. (JAKIM, 2012). In 1995, JAKIM introduced a more comprehensive solah time to help the public in solah times, beginning and ending.

The computation of zoning solar times is based only on a single point of reference for a given zone, yet its application is extended to larger zones (Subari, 2015). Before solah times coordination, solah times for many areas are followed by those of their larger townships. This resulted in too many Sola sub-areas in various districts in many states (Adnan, t.t). Therefore, the coordination of solah times will enable the public to conveniently monitor their solah times according to the zones determined by the authority.

The States' Islamic religious authority has a validation authority for selecting methods and determining the reference point for a given solar time zone. Criteria, as set out in the directives issued by the JAKIM Areas, are as follows:

i. Each zone of solah times shall not exceed 2 minutes of difference.

ii. The reference station must be in the western-most part of the zone.

iii. Highland areas, such as the hill or mountain, or the island, must have their solah times.

The 2-minute difference means that the solar time between the eastern and western zones of the zone is not more than or equal to 2 minutes. The specification of the 2-minute range refers to the average duration of 1 rakaat of regular solah. The rate of 2 minutes is agreed upon by the Muftis State Consensus, as it does not infringe the tahrim (forbidden) of solah. The intention is to fulfill the obligation to perform solah as earliest as possible. (Saupi, 2005).

\subsection{Factors Influencing Determination Of Solah Times}

The earliest method practised by Prophet Muhammad SAW was by visual observation of the sun's movement, i.e. the sun passing past the noon sky meridian for Zohor; the subsequent change of the shadow length for Asar; and the sun setting in the west for Maghrib; the changing shades of the night sky for Isyak, and the rising of the fajr sadik for Subuh. The sun's position is practical for its determination, given the command that the five obligatory solahs must be performed within a specified time.

Scientific observations of the Earth's rotation and its revolution around the sun greatly benefit the determination of times for Muslims' daily Ibadah. Al-Qu'ran in Surah Yunus, verse 5:

\subsubsection{Sun Position}

"It is He who made the sun a shining light and the moon a derived light and determined for its phases - that you may know the number of years and account [of time]. Allah has not created this except in truth. He details the signs for people who know. Indeed, in the alternation of the night and the day and [in] what Allah has created in the heavens and the Earth are signs for a people who fear Allah".

Various hadiths explain the times for the beginning and the end of the obligatory solah. In practice, Falak experts have worked to determine the sun's position as a marker at the beginning of each solar time (Jabatan Mufti Selangor, 2005).

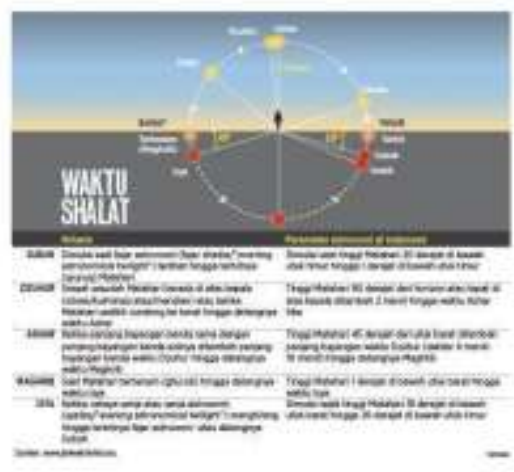

Figure 1: Position of the Sun and Solah Times

(Source: https://asset.kompas.com/data/photo/2013/07/17/1833299penentuan-waktu-shalat-dan-puasa1780x390.jpg) 


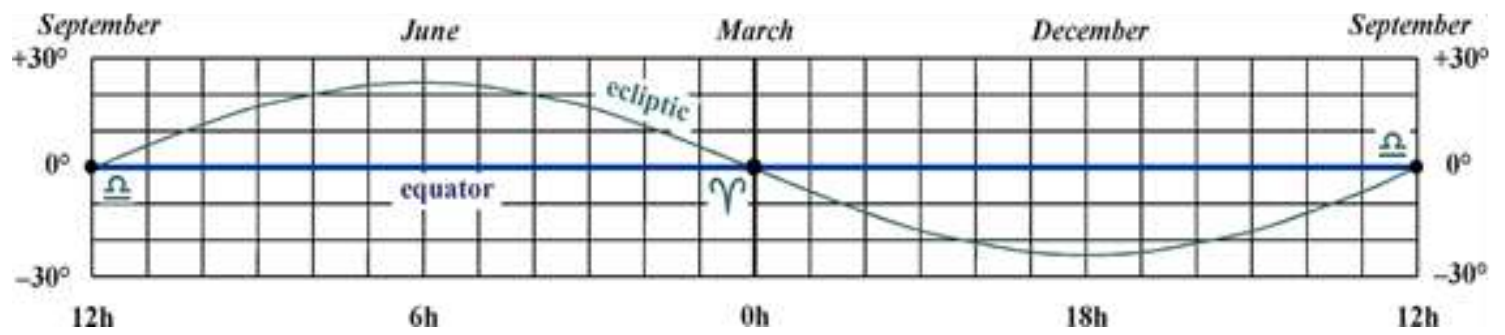

Figure 2: Yearly Ecliptic Path (Source : http:// www2.arnes.si)

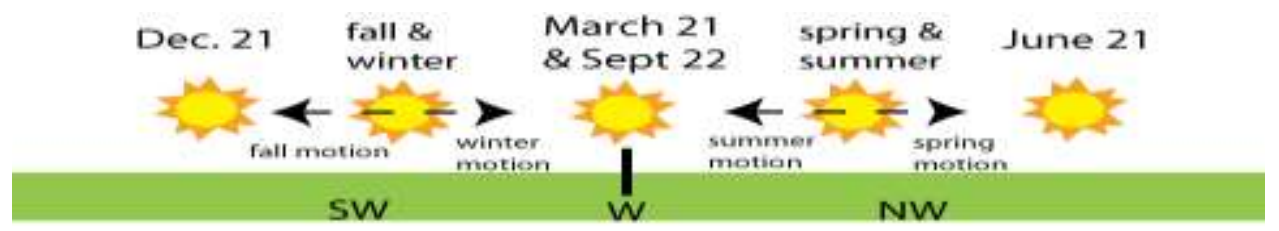

\section{Sunset position changes throughout the year. Note: change "W" (west) to "E" (east) for the sunrise position.}

Figure 3: Yearly Sun Rise Position

(Source: http://www.astronomynotes.com/nakedeye/sunset-position.png)

The sun rises directly at the eastern point and sets just twice a year at the western point, on March 21 and September 23 in the equatorial zones. On both dates, the sun passes right on the Zenith (point directly above one's head) during Istiwa (sun directly above the Kaabah), and there is no shadow cast. After March 21, the sun will rise to the North of the eastern point and reach a maximum of June 22. On these dates, the sun will not pass directly over Istiwa; it will be far to the North.

After June 22, the sun will again move south and cross the Equator on September 23. After September 23, the sun moves south from the east point to a maximum of December 22. After that date, the sun will rise to the east again. This phenomenon is due to the Earth's position relative to its orbital revolution around the sun, tilted at $23.5^{\circ}$ on its axis (Baharrudin, 2004).

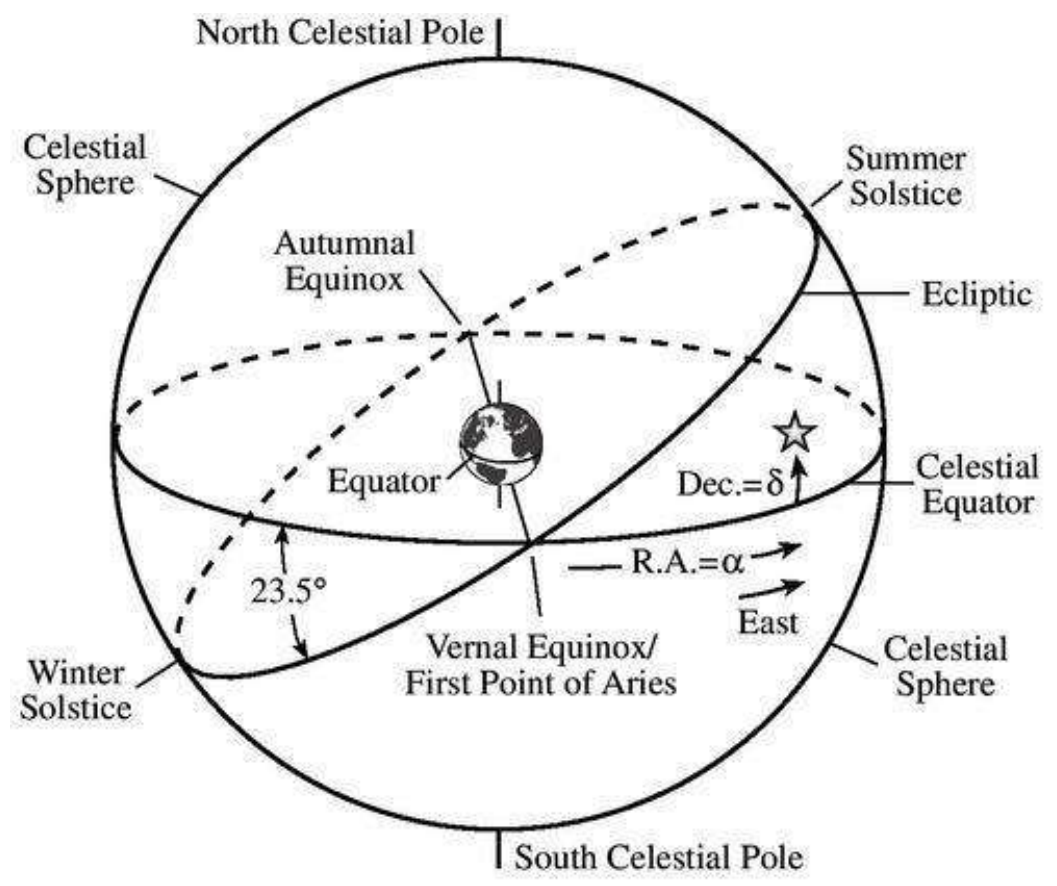

Figure 4: Observable Sun Revolution in a Year (Source: https://ase.tufts.edu/cosmos/view_picture.asp?id=1387) 


\subsubsection{Latitude and Longitude Reference Coordinates}

Latitude refers to the Earth's surface between the equator and the North or south poles. It can be specified as an angle from the $90^{\circ}$ vertical line of the surface to the equator's line in the Earth's centre (Faris, 2003). According to the geometrical calculation, the reference station's latitude equals the station's celestial pole's height or altitude.

Longitude is a circle of lines set at a right angle, marking the latitude's east-west position, known as the meridians. It is seen as a place's distance angle, whether located on the east or west of the Main Meridian Line (David, 1951).

No specific meridian can be a starting line because no fixed point is used as a basis for computing, given the Earth's constant motion on its axis. Theoretically, any median can be chosen as the starting point, and the location of East and West can be calculated by measuring the distance of angles along the lines of the Earth circle.

However, in the 19th century, the (Royal Greenwich Observatory) in London, England, was chosen as the primary meridian, at $0^{\circ}$, which became the point of division between the Eastern and Western meridians. The longitude meridian is an imaginary line, measured in angular degrees of the Earth's surface from the North Pole to the South Pole, which connects all locations at the exact longitude (Thor, 2002).

\subsection{Methodology}

This qualitative study uses a library research method to gain data regarding the practices and methods employed to determine the zonal solah times in the Malaysian states. The data was collected from previous studies through journal articles, books, working papers, and websites. In completing the data, this study also obtained supporting sources by interviewing the related authorities. The literature was analyzed using the content analysis method, while interview data were analyzed via thematic analysis.

\subsection{Findings}

The findings indicated several methods for determining zone-based solar times in Malaysia, either officially used by the States or only for academic research or research by Falak experts. The most-western point and multiple points are the official methods. At the same time, academic research refers to the method of Isotime.

\subsection{Most-western Point Method}

The findings indicate that this method is being used officially by many states in Malaysia, such as Selangor, Johor, Melaka, Kelantan, Perak, Negeri Sembilan, Terengganu, Pahang, Sabah and Sarawak. This method shall determine the earliest solah time of a particular zone, utilizing a reference point that must be at the western-most point of the area or zone.

This reference point selection considers that the solar track of rising in due east and setting in due west is considered in determining the western-most point. This means that when the eastern region enters solah time, the western part is still not there. Therefore, it is only necessary for Muslims in the eastern regions to wait a little longer until the western regions have entered solar time.

Theoretically, this method is suitable for a small zone with a simple geometrical landscape, as if it were squarish in the perimeter. Let us take a picture of an area with two villages (A) and two villages (A) (B). According to zonal solah times, Zuhr for Village $A$ is at 1.10 p.m., while for Village $B$ it is at 1.12 p.m. Therefore, the Zuhr solah times for the zone in which the villages $A$ and $B$ are located and the other villages in the vicinity are at $1.12 \mathrm{p} . \mathrm{m}$. The end times for the solah, however, will become a matter in a hypothetical case. When a Village A resident, who is likely to perform his Zuhr, does not do so within the prescribed time. This may be the case if the sun's actual movement is a reference, that Village A solah time may have ended, while the village is waiting for the end of the solar time in Village $B$, in the western part of the zone.

However, the end of solah time is not a priority for the determination of compulsory solah times. Although it is not generally stated for the public in solah times, it is nevertheless essential for the determination of syuruk. After the end of Subh times, Syuruk begins. Zones or areas are not all of the small size and geometrically simple landscape. Therefore, the time difference within a particular zone may exceed 2 minutes (Abdul Halim, 2015).

This method is relatively ineffective for large zones or areas where the time difference between the east and west zones can be 4 minutes (Paidi, 2015). The 2-minute criteria set by JAKIM are therefore not met. Effects are also felt at the border of the zones, with a range that may exceed 2 minutes, especially if the zones are in different states.

\subsection{Multiple Reference Point Method}

Multiple Reference Point is a method introduced by Tuan Haji Abdul Majid bin Abdul Wahid, a takwim expert from Kedah ((Abdul Majid, t.t) (Abdul Majid, t.t). It is an alternative method for the determination of zonal solah times. However, until today, only the state of Kedah officially employed this method, but not other states. Nevertheless, academic research attempted to apply this method in other states such as Pulau Pinang, Terengganu, and Kelantan (Abdul Halim, 2015) dan Selangor (Paidi, 2015). (Paidi, 2015).

This method selects several points around the border of a given zone for the calculation of solah times. The point indicated last to enter solah time would be used as a point of reference for the beginning of solah time for the zone. A point taken to determine a given solah time is not necessarily the same point for every other season. Given that the constant Earth revolves around the sun, with the axis tilted at $23.5^{\circ}$, reference points changed according to the zones' seasons and relief. Hence, the changes in the declination values of the sun all year long. Although this method can resolve several issues from the western-most method, it is still not quite refined. Among the 
issues attributed to this method is the lack of specific criteria for selecting the reference point. That, the points of reference are a random selection obtained from google earth software.

\subsection{Isotime Method}

The Isotime method uses similar timelines to check the current time zones (Mohamad Saupi, 2012). This method shared similar techniques with the Multipoint Reference Method, referring to Earth moving around the sun at $23.5^{\circ}$ tilt. Nurul Asikin Che Daud and Mohamad Saupi Che Awang (Nurul Asikin, 2012) used Isotime and Diagonal methods in their 3-phase research. The primary data used were the solar times for 2012 and 2020, based on the four dates of March 21, June 22, September 23 and December 22. This study was conducted in several states such as Selangor, Johor, Pahang, Kelantan, Sabah and Sarawak.

Phase 1 is the initial stage for building a database for solah times using e-solat, obtained from JAKIM (2012) and i-Solat by Hairie Ikham Sibaruddin (2009). For Phase 2, an isotime formulation is used for each state using the surfer v10 software. While the final phase 3 is for the analysis of zonal solah times based on isotime, compared to JAKIM solah times in Microsoft Excel. The isotime computation for five solah times, including one for syuruk on selected dates, is based on four corner points' map coordinates as a reference. The isotime is then overlapped over the computed solah times on the state map to identify and delineate the state zones' boundaries.

Their findings indicated a 4-minute difference between zone 1 and zone 2, a 5-minute difference between the eastern and western regions. So, the same is true for Sarawak, where the difference can reach 5 minutes. The research suggested an increase in the number of new 2-minute zones up to 76 for all Malaysian states to replace the 55 currently prevalent zones. However, this method is still limited for research purposes and has not been officially adopted by any State in determining its solar zoning time.

\subsection{Conclusion \& Recommendations}

Guidelines for determining solah times have been set out in the Al-Quran and clarified in the hadiths. There are, however, challenges in adapting them to practices. Various factors may influence the determination of the solar times that need to be considered and addressed. This is compounded by a lack of expertise in the methods and concerns expertise on the zones' nature. These issues have given rise to various ideas on the determination and computing of solah times, resulting in a lack of consensus on how to resolve the issues.

Various methods have been introduced and used for the determination of zonal solah times in Malaysia. The Western-most point and the Multipoint Reference are among them. Almost all states in Malaysia use it officially for the western-most point. However, this method's issue is that it may have a time difference that exceeds 2 minutes, particularly for border areas of the zone. This method also results in stark differences of about 4 minutes between the zone's eastern and western regions.

The Multipoint Reference is, therefore, an alternative method introduced to deal with the issues. This method is effective in minimizing the time difference in border areas of the zones. However, this method is still ineffective in larger areas.

In conclusion, all methods used to determine and calculate solar times are still inadequate and inefficient. Based on the findings, the researcher may conclude that the determination of solah time may rely on a few circumstances and the views of experts. Although the choice of methods is a matter for the States' Islamic authorities, JAKIM should lay down standard guidelines for using methods for more reliable solah times. This guideline shall prevent confusion among Muslims as a result of unverifiable differences in times of solah. Therefore, further research by academics and Falak experts to improve the determination and computation of solah times is essential.

\section{Acknowledgement}

This research was funded by the LESTARI grant 600-IRMI/DANA KCM 5/3/LESTARI (188/2017) of the Institute of Research Management Centre, Universiti Teknologi MARA (UiTM).

\section{References}

Abdul Halim Abdul Aziz (2015), Kaedah Panca-Titik Dalam Menentukan Waktu Solat Zon, Jurnal Falak, Putrajaya : JAKIM

Abdul Majid Abdul Wahid, (t.t), Waktu Ibadat dan Takwim:Kaedah dan Penggunaan Bagi Negeri Kedah Darul Aman, Kedah:Annasyir Sdn Bhd.

Baharrudin Zainal (2004), Ilmu Falak Edisi Kedua, Kuala Lumpur : Dewan Bahasa Dan Pustaka

David Greenhood (1951), Down To Earth: Mapping For Everybody, New York: Holiday House.

http:// www2.arnes.si.Retrieved March 10, 2019.

http://www.astronomynotes.com/nakedeye/sunset-position.png. Retrieved March 25, 2019.

https://ase.tufts.edu/cosmos/view_picture.asp?id=1387. Retrieved March 27, 2019.

https://asset.kompas.com/data/photo/2013/07/17/1833299penentuan-waktu-shalat-dan-puasa1780x390.jpg 
Md Adnan bin Md Daud (t.t), Penyelarasan Waktu Solat Di Malaysia, JAKIM.

Mohamad Saupi Che Awang (2005), Penyelarasan Ihtiyati Dalam Waktu Solat : Pandangan Teknikal, Muzakarah Jawatankuasa Teknikal Kalendar Islam, Kuala Terengganu.

Mohamad Saupi Che Awang (2012), Penambahbaikan Zon-zon Waktu Solat Di Malaysia Menggunakan Kaedah Isotime, Mesyuarat Penyelarasan Zon-zon Waktu Solat Seluruh Malaysia.

Mohamad Saupi Che Awang, (1994), Kaedah Perhitungan Waktu Solat: Satu Tinjauan, BULETIN UKUR, Jilid 5, No.3, Fakulti Ukur Dan Harta Tanah, UTM, Johor. Oktober, 1994

Mohd Faris Dziauddin, Ruslan Raini (2003), Pengenalan Kepada Kartografi, Prentice Hall, Pearson Malaysia Sdn Bhd.

Mohd Paidi Norman (2015), Penggunaan Kaedah Titik Paling Barat Dan Kaedah Panca Titik Rujukan Dalam Penentuan Waktu Solat Berasaskan Zon : Kajian Di Selangor, disertasi Sarjana, Jabatan Fiqh Usul, Akademi Pengajian Islam Universiti Malaya, Kuala Lumpur.

Mustafa Din Subari, Mohamad Saupi Che Awang (2015), Waktu Solat Setempat : Satu Pemurnian Kepada Waktu Solat Berasaskan Zon, Jurnal Falak, Putrajaya : JAKIM.

Mustofa al-Khin, Mustofa al-Bugh, Ali asy-Syarbaji, (2003), al-Fiqh al-Manhājī „alā Madhāhib al-Imām as-Syāfi"ī, Jil. 1, (Damsyiq : Dār al-Qalam)

R.B Bunnet et.al (1970), General Geography, Kuala Lumpur: Longman Malaysia Sdn. Bhd.

Thor Bernhardsen (2002), Geographic Information Systems: An Introduction, New York: Joh Wiley \& Sons. 